Bond University

Research Repository

\title{
Estimation of a Term Structure Model of Carbon Prices through State Space Methods: The European Union Emissions Trading Scheme
}

Aspinall, Thomas; Gepp, Adrian; Harris, Geoffrey; Kelly, Simone; Southam, Colette; Vanstone, Bruce J

Published in:

Accounting and Finance

DOI:

10.1111/acfi. 12708

Licence:

Other

Link to output in Bond University research repository.

Recommended citation(APA):

Aspinall, T., Gepp, A., Harris, G., Kelly, S., Southam, C., \& Vanstone, B. J. (2021). Estimation of a Term Structure Model of Carbon Prices through State Space Methods: The European Union Emissions Trading Scheme. Accounting and Finance, 61(2), 3797-3819. https://doi.org/10.1111/acfi.12708

\section{General rights}

Copyright and moral rights for the publications made accessible in the public portal are retained by the authors and/or other copyright owners and it is a condition of accessing publications that users recognise and abide by the legal requirements associated with these rights.

For more information, or if you believe that this document breaches copyright, please contact the Bond University research repository coordinator 


\title{
Estimation of a Term Structure Model of Carbon Prices through State Space Methods: The European Union Emissions Trading Scheme
}

\begin{abstract}
:
This study models the term structure of the European Union Emissions Trading Scheme. Abadie \& Chamorro's (2008) one-factor Geometric Brownian Motion model is replicated using the data now available and then compared with a two-factor Short-Term/Long-Term (STLT) stochastic model. The STLT model has the better statistical fit to the term structure of European Union Allowances (EUAs). A Real Options Analysis of the value of the option to retrofit Carbon Capture and Storage shows that forecasting phase four EUAs with the STLT model almost triples the estimated project Net Present Value and lowers investment trigger prices by approximately $24 \%$.
\end{abstract}

\section{Introduction:}

The European Union (EU) Emissions Trading Scheme (ETS) is the world's largest and oldest cap-andtrade carbon pricing system. Introduced in 2005, the EU ETS was established as a key method of EU member parties reaching emission reduction goals set in the Kyoto Protocol. Since the inception of the EU ETS, spot and derivative markets for European Union Allowances (EUAs) have grown substantially in size, stability, and liquidity. Trading periods in the EU ETS are divided into distinct trading phases. Phase two (2008-2012) and three (2013-2020) of the EU ETS experienced a depression and long-term downward trend in the price of EUAs (Figure 1) due to surplus in EUAs as a result of the 2008 Global Financial Crisis (Clara and Mayr, 2018). This provided little incentive for participating companies to lower $\mathrm{CO}_{2}$ emissions during this time period (Ellerman et al., 2010; Pindyck, 2013). Phase four (20212030) market reforms were formally approved by European Lawmakers in early 2018 (Clara and Mayr, 2018) with a focus on restoring market balance. The market responded favourably to these reforms, with EUA prices experiencing a strong surge from 2018 onwards.

This study investigates the effect of long-term EUA pricing signals on private investment decisions into emissions reduction technology by modelling the price dynamics of the second and upcoming fourth phase of the EU ETS through state-space methods. The one-factor stochastic model for phase two carbon prices (2008 - 2012) estimated by Luis M. Abadie and Jose M. Chamorro (2008) is replicated and directly compared to contemporary phase four estimates. Abadie and Chamorro (2008) applied Kalman Filtering to estimate a Geometric Brownian Motion (GBM) stochastic model to forecast phase two carbon prices, and subsequently (using a lattice approach) valued the option to install a carbon capture unit to a coal-fired power plant. Parameter estimates from this model have been since applied within several studies to value carbon capture investments (Heydari et al., 2010; Knoope et al., 2015a, 2015b; Mo and Zhu, 2014). This initial work by Abadie and Chamorro (2008) determined that the pricing signal generated by the EU ETS was not strong enough to trigger investment, but noted that changes in market structure and carbon market parameters could change optimal investment decisions.

The EU ETS has matured and experienced considerable structural changes since the publication of Abadie \& Chamorro's work, warranting a re-parameterisation of the stochastic model of carbon prices. The trading rules during the first two trading phases of the EU ETS differed in important aspects to those of the third and upcoming fourth phase. Rather than EU member countries setting national caps on emissions, the EU ETS now operates under a single EU-wide cap on emissions (World Bank Group, 2016). Auctioning is now the default method of allowances allocation rather than free allocations, with the electricity production industry no longer eligible for free allocations (European Commission, 2020). 
In phase two of the EU ETS, no more than $4 \%$ of EUAs were auctioned and $90 \%$ free allocated (World Bank Group, 2014), whilst this number increased to approximately $40 \%$ of allowances auctioned at the beginning of the third phase of the EU ETS (World Bank Group, 2016), with zero free allocations scheduled within phase four of the market by 2025 (European Commission, 2020).

Expanding on the forecasting of EUAs through a one-factor GBM model, this study adopts the twofactor Short-Term/Long-Term (STLT) model proposed by Schwartz and Smith (2000) to evaluate shortterm and long-term dynamics of the market for EUAs. This model has the benefit of featuring the GBM and Geometric Ornstein-Uhlenbeck (MR) models as restricted models, which allows for goodness-offit testing between one-factor and two-factor models to directly compare their abilities to capture the dynamics of futures prices. Five stochastic models for EUA spot prices are estimated using two sets of daily quoted futures market data listed on the Intercontinental Exchange (ICE) that expire within phase two and four of the EU ETS. Estimated stochastic models are used to investigate changes in market dynamics of EUAs as the EU ETS has matured. Estimated stochastic models are subsequently applied to the initial case study of Abadie and Chamorro (2008) using the Least-Squares Monte-Carlo (LSM) Simulation method to determine how carbon pricing signals under the EU ETS have influenced investment in carbon reduction technologies.

Following this, Section 2 describes the price drivers and historical changes to the EU ETS that have occurred since market inception. Section 3 then describes the data used, and Section 4 introduces State Space Methods and parameter estimates of the GBM and STLT model. Section 5 discusses the carbon capture case study of Abadie and Chamorro (2008) and introduces the Least-Squares Monte-Carlo (LSM) simulation solution method. Section 6 presents a replication of this case study and the effect of stochastic modelling assumptions and contemporary parameter estimates on calculated project value and investment trigger prices. Finally, Section 7 summarises and concludes this work.

\section{Term Structure of Commodities}

Stochastic models and parameters used to forecast commodity prices are typically developed through investigation of the term structure, as futures prices consider future supply and demand conditions as well as market expectations on future price movements (Lautier and Galli, 2004). EUA prices have been shown within existing literature to behave as very specific commodity markets, "with distinct fundamentals linked to allowance supply and power demand" (Chevallier, 2009, p. 614). The analysis of the term structure of commodities attempts to relate the unobservable components of the futures price curve with observable economic variables. Calibration and estimation of unobservable quantities can be naturally performed through filtering. The Kalman Filter is a recursive algorithm that develops the optimal estimator of states of a dynamic system expressed in State Space form (Kalman, 1960). Parameter estimation of commodity price models through Kalman Filtering and state-space methods were popularised within the works of Gibson and Schwartz (1990); Schwartz (1997, 1998); Schwartz and Smith (2000), which expressed the futures curve in terms of unobserved factors and derive futures prices under no-arbitrage conditions.

The long-term forecasting of EUA spot prices within existing literature has primarily been performed using a GBM model with positive drift term to reflect an increasing scarcity of allowances. These forecasts are then used to examine investment under carbon pricing uncertainty. Abadie and Chamorro (2008) estimated a GBM model after summary statistics of futures contracts revealed a direct relationship between annualised volatility and time-to-maturity. $\mathrm{CO}_{2}$ pricing scenarios required to limit global temperature increases have shown approximately linear long-term $\mathrm{CO}_{2}$ price increases, implying GBM is appropriate to model this behaviour (Hauck and Hof, 2017; Knoope et al., 2015a; Laude and Jonen, 2013). GBM was also determined to be suitable in phase two, as immature carbon markets possess low levels of liquidity and high market concentration (Daskalakis et al., 2009; Rammerstorfer and Eisl, 2011). This modelling choice was supported by several other studies that evaluated the early phases of the EU ETS, of which Hintermann et al. (2016) provide a summary and review. In an 
extension to the GBM model, Rammerstorfer and Eisl (2011) model carbon prices with both linear and mean-reverting convenience yields, representing different levels of maturity in the carbon market. This model was first proposed by Gibson and Schwartz (1990) and has been proven within the work of Schwartz and Smith (2000) to be equivalent to the two-factor STLT model.

The two-factor STLT model proposed by Schwartz and Smith (2000) is one of the most popular models for modelling commodity prices. The stochastic model decomposes spot prices of a commodity into the exponential sum of short-term deviations, $\chi_{t}$, and long-run equilibrium prices, $\xi_{t}$.

Let $S_{t}$ denote the spot price of a commodity at time $t$ :

$$
\ln \left(S_{t}\right)=\chi_{t}+\xi_{t}
$$

Where Short-run deviations $\left(\chi_{t}\right)$ are assumed to revert at a mean reversion rate $\kappa$ toward $-\lambda_{\chi} / \kappa$ with a half-life of $\ln (2) / \kappa$ following an Ornstein-Uhlenbeck process, and long-run equilibrium prices $\left(\xi_{t}\right)$ are assumed to follow Brownian Motion. Under the assumption of risk-neutrality, $\chi_{t}$ and $\xi_{t}$ are given by:

$$
\begin{gathered}
d \chi_{t}=\left(-\kappa \chi_{t}-\lambda_{\chi}\right) d t+\sigma_{\chi} d z_{\chi}^{*} \\
d \xi_{t}=\left(\alpha_{\xi}-\lambda_{\xi}-\frac{1}{2} \sigma_{\xi}^{2}\right) d t+\sigma_{\xi} d z_{\xi}^{*}
\end{gathered}
$$

Where $d z_{\chi}^{*}$ and $d z_{\xi}^{*}$ are increments of a standard Brownian motion process with $d z_{\chi}^{*} d z_{\xi}^{*}=\rho_{\chi \xi} d t$

The intuition behind this model is that the term structure of a commodity can be explained by the evolution of a long-term equilibrium and short-term deviations from this equilibrium. The assumption when $\kappa$ is high is that the difference between short-term deviations and the long-term mean will tend towards zero (Sauvageau and Kumral, 2018). Over the lifetime of the EU ETS, the market for EAUs has been characterised by consistently high levels of volatility and experienced several structural breaks and market failures. Following Laurikka and Koljonen (2006) and Hintermann et al. (2016), Carbon prices are said to be influenced by the supply, method of allocation to participants and transparency of future market policies. Short-term deviations are typically driven through supply and demand. The freeallocation and ability for participants to bank allowances between phases directly effect the supply of allowances. Weather, changes in prices to commodities such as oil, gas and coal and the impact of macro-economic conditions on production levels can influence demand for emissions allowances. Long-term changes in EUA prices can be said to be driven by expectations of future regulatory policies, subsidies and technological improvements in low carbon technology.

***Insert Figure 1 approximately here ${ }^{* * *}$

Figure 1. Historical Futures Prices of the European Union Emissions Trading Scheme

\section{Data}

\section{***Insert Table 1 approximately here***}

Table 1 describes the data used in this study to estimate the parameters of stochastic models to forecast EUA spot prices. Data sets in this study are labelled according to the phase in which the quoted futures prices expired in, rather than the phase that time-series observations were quoted from. Abadie and Chamorro (2008) develop a stochastic model to forecast carbon prices using 2006 - 2007 quoted futures data of contracts expired within the second phase of the market. The model applied daily prices $\left(€ / \mathrm{tCO}_{2} \mathrm{e}\right)$ for EUA futures prices listed on the Intercontinental Exchange (ICE), where one contract is for $1,000 \mathrm{tCO}_{2} \mathrm{e}$. The work of Abadie and Chamorro (2008) used quoted futures prices for five contracts with December expiries due to sparse trading of other contracts. Futures markets have grown 
substantially in trading volume since this publication, allowing for futures contracts with other expiries to be included within the phase four dataset. Contracts within the phase four dataset are stitched together, with a roll-over frequency of three months to capture the short- and long-term dynamics of the market (see Schwartz (1997)). Observation dates of phase two data were set directly after an initial recovery in EUA spot and futures price declines due to market failure resulting from a confirmed oversupply of EUAs in phase one (2005-2007). Phase four futures contracts were first made available in February 2017, but revisions for reforms were not formally declared and signed until early 2018. EUA market prices have experienced substantial growth since early 2018 and this observed structural break is selected to forecast EUA spot prices moving into phase four.

\section{Parameter Estimation}

The Kalman filter facilitates the calculation of the likelihood of observing a particular data series given a specific set of model parameters; this allows us to estimate parameters using maximum likelihood. The Kalman filter is characterised by a transition and measurement equation, presented in the work of Schwartz and Smith (2000). Maximum Likelihood Estimation was performed using Genetic Algorithms through the Genoud optimisation algorithm, first introduced by Mebane Jr and Sekhon (2011). The Genoud algorithm applies a genetic evolution strategy with derivative-based methods to solve difficult optimisation problems (Mebane Jr and Sekhon, 2011). Richardson's Extrapolation was applied to numerically approximate the gradient function.

\section{***Insert Table 2 approximately here ${ }^{* * *}$}

The STLT model includes the one-factor GBM and MR models by considering uncertainty in only one of the two state variables. The relevant test statistic for model comparison is a $\chi^{2}$ test statistic with 3 degrees of freedom; the $99.9 \%$ critical value of 16.27 is used to determine whether the additional parameters of the two-factor model improve the fit. Estimated log-likelihood scores for the STLT model are significantly larger than the one-factor models across each phase dataset (Table 2), indicating that the additional ability for the two-factor model to explain the term structure over the one-factor models is large and statistically significant. Mean-reverting rates $(\kappa)$ for the MR models were estimated to the lower bounds (1E-5) of the optimisation algorithm for both phase two and four; that is, a random walk, suggesting that the term structure of the EUAs cannot be explained through a single factor with meanreverting behaviour. Given that the GBM model is the primary stochastic model used to forecast EUA spot prices in existing literature, and that the STLT model has the greatest fit over both one-factor models, the MR model is not considered further.

\section{***Insert Figure 2 approximately here***}

Figure 2. Errors in the Model Fit to the Logarithm of Futures Prices

Figure 2 illustrates that the two-factor STLT models fit the term structure of the futures prices better than the one-factor GBM models for each contract. Root Mean Squared Error (RMSE) scores for each observable futures contract are low for both models across each dataset, indicating each estimated model's ability to describe the observable term structure for EUAs. The errors of the GBM models fit the mid-term contracts best with larger errors for the shorter and longer-term contracts, whilst the STLT models have less disparity between contract errors. The standard deviation of the measurement error is selected within the parameter estimation method to maximise the likelihood of, and provide the best overall fit to, the data. Prices in each period can be perfectly matched for each contract up to the number of state variables of the stochastic model (Schwartz and Smith, 2000).

$$
\text { ***Insert table } 3 \text { approximately here }{ }^{* * *}
$$

Table 3 presents the maximum likelihood estimates and corresponding standard errors for all models, including a replication of the initial model of Abadie and Chamorro (2008). There are observable 
differences in the estimated parameters across the different panel datasets, indicating that the EU ETS has experienced structural and behavioural changes since the initial work of Abadie and Chamorro (2008). Interestingly, the EU ETS has not experienced a decrease in volatility as the market has matured, indicating that there is still a great deal of uncertainty regarding future price paths of the commodity. Correlations between the mean-reverting and random walk long-term factors are low, with the correlation coefficient for the phase two data estimated at less than $1 \%$, suggesting that the model has identified two independent price drivers within phase two of the EU ETS. The random walk processes of the STLT models feature lower volatility and higher drift terms in comparison to GBM models, suggesting that approximately $4-5 \%$ of the volatility of EUAs can be expressed as a separate factor with a low correlation coeffcicient. Estimated mean-reversion parameters for the STLT models $(\kappa)$ are low, with estimated half-lives of phase two and four models being 3.86 and 2.82 years respectively, indicating that there is evidence of mean-reverting behaviour within the market for EUAs, but they are primarily governed by a random walk.

\section{Case Study:}

The purpose of this case study is to directly compare the commercial viability of retrofitting CCS technology under carbon pricing uncertainty. First presented within the work of Abadie and Chamorro (2008), this case study considers a Super Critical Pulverized Coal (SCPC) power plant with a residual lifetime of 40 years that is considering retrofitting a carbon capture unit. Table 4 lists the financial parameters of this case study.

Increases in the scarcity of EUAs drives long-term future prices upwards, but specific price paths of these allowances remain unknown, providing participants with flexibility regarding how, when and if they respond to these economic signals. Modelling and forecasting the long-term prices of EUAs is a critical problem for participants evaluating private investment in emission abatement projects under carbon pricing uncertainty. The Energy production industry finds the optimisation of timing reactions to climate policy signals to be a critical problem (Fan et al., 2019), as underinvestment in mitigation technology risks losing an early-mover advantage whilst over-investment could lead to scarce resources committed to mitigation as more profitable opportunities arise (Fuss et al., 2008). Optimal timing of investment into emission abatement options has been suggested to have the potential to "fundamentally reshape future market positions of energy companies (due to) technological path-dependencies and lags of policy responses to global warming signals" (Fuss et al., 2008, pp. 708-709).

CCS is the process of capturing anthropogenic emissions from large point sources for long-term storage and isolation from the atmosphere through injection into appropriate geological rock formations (IPCC, 2005). Whilst CCS requires greater energy to facilitate the capture and storage of emissions, it is capable of a net reduction in $\mathrm{CO}_{2}$ emissions of a point source of up to $90 \%$ (IPCC, 2005). CCS can be both inbuilt during the construction of new point sources or built onto existing point sources (retrofit) at a higher cost and lower efficiency (Reinelt and Keith, 2007). Bibliometric studies (Li et al., 2019; Yu et al., 2016) have determined that the evaluation of the investment decision to invest in low-carbon energy technologies and CCS technology under carbon pricing uncertainty has typically been performed through ROA. Studies that have evaluated CCS technology have applied a variety of different financial inputs and stochastic model parameters, which can make the direct comparison of results difficult or invalid, even when they have applied similar valuation methods or case studies (Rubin, 2012). Existing literature that has applied ROA to value CCS technology has determined that the commercial viability of retrofitting CCS technology is highly dependent on strong carbon-pricing signals, transparent, longterm government commitments and higher existing prices of carbon (Abadie and Chamorro, 2008; Fuss et al., 2008; Mo et al., 2015; Zhou et al., 2014; Zhou et al., 2010; Zhu and Fan, 2011, 2013). Evaluation of the comparative propensity to retrofit CCS technology has also been considered under both 
deterministic carbon taxes and stochastically evolving ETS (Blyth et al., 2007; Compernolle et al., 2017; Knoope et al., 2015a; Szolgayova et al., 2008; Walsh et al., 2014).

\section{***Insert table 4 approximately here ${ }^{* * *}$}

The option to retrofit CCS technology is a function of stochastic carbon allowance and wholesale electricity prices as retrofitting CCS technology to an SCPC plant reduces total electricity production due to the energy required to capture, condense, transport and store $\mathrm{CO}_{2}$ emissions (Abadie and Chamorro, 2008; Abadie et al., 2014; Rohlfs and Madlener, 2011; Zhu and Fan, 2011, 2013). Stochastic parameters for electricity prices were estimated by Abadie and Chamorro (2008) (Table 5) through an Ordinary Least Squares (OLS) regression applied to monthly average prices of Spanish Wholesale Electricity Prices (OMEL) for an inhomogeneous GBM model, which corresponds to an Autoregressive model of order 1 ((Abadie and Chamorro, 2008), see also (Abadíe, 2007).)

Let $E_{t}$ denote the price of electricity at time $t$ :

$$
d E_{t}=k_{e}\left(L_{e}-E_{t}\right) d t+\sigma_{e} E_{t} d W_{t}^{E}
$$

Where, $L_{e}$ denotes the equilibrium price, $k_{e}$ is the rate of mean-reversion and $\sigma_{e}$ is the instantaneous volatility. The stochastic model for electricity estimated by Abadie and Chamorro (2008) is applied within this case study (Table 5), with the estimated correlation between carbon and electricity prices applied to both factors for the STLT models. This allows for direct comparison between the modelling assumptions of EUA prices and the pricing signals generated by the EU ETS. This case study uses up to three stochastic variables.

\section{***Insert table 5 approximately here***}

The option to retrofit CCS technology is classified as an American call option with dividends equal to the cash flows accrued through investment. Calculating the value of an American option requires finding the optimal exercise rule through the solution of an optimal stopping problem and computing the expected discounted payoff of the option under this rule (Glasserman, 2004). At any time, the SCPC plant evaluates the decision to exercise the option to retrofit CCS technology or delay the exercise decision. Optimal investment timing and the value of the option to retrofit CCS is solved in this study through the LSM Simulation method proposed by Longstaff and Schwartz (2001). The LSM simulation method is a dynamic programming method that solves for the value of an American option through the regression of economic values across simulated price paths in each period on a linear combination of a set of basis functions of underlying stochastic variables. The LSM simulation technique is considered the most flexible real options valuation method that is comparatively easy to implement, particularly for multi-dimensional problems, with Schwartz (2013) concluding "it is intuitive, transparent, flexible, easily implemented, and computationally efficient" (p. 167). The option value of retrofitting CCS technology is calculated by discounting the payoffs of investing at the optimal investment timing calculated through the backwards induction process and averaging across all price paths. For an example on solving for CCS option values through the LSM Simulation method, see Mo et al. (2018) section 2.3 .

Continuation values in this case study were approximated using cross products of Carbon and Electricity state variables and the first nine Laguerre polynomials (see Abramowitz and Stegun (1965)) although project values were determined to be insensitive to the choice of orthogonal polynomial and degrees higher than nine. The LSM Simulation method was performed using 100,000 simulations (of which $50 \%$ were antithetic) and a discrete-time step of six per year. Projects under phase two and four stochastic models were estimated at an initial carbon price of $18.02 € / \mathrm{tCO}_{2} \mathrm{e}$ and $25.61 € / \mathrm{tCO}_{2} \mathrm{e}$ respectively. 


\section{Results and Discussion:}

Calculated project values under the different estimated stochastic models are presented in Table 6 . Estimated project values and trigger prices of investment are highly sensitive to modelling assumptions, investment criteria and ROA solution methods. The trigger prices of investment under the ROA investment criteria are much higher than that of the Net Present Value (NPV) criteria because of the uncertainty of future carbon price paths and corresponding risk associated with retrofitting CCS technology. Trigger prices of investment are substantially lower using the LSM simulation method in comparison to a lattice approach, despite comparable NPV, real option values (ROV) and waiting option values (WOV); however, the effect of ROA solution methods on trigger prices is not the focus of this study.

\section{***Insert table 6 approximately here ${ }^{* * *}$}

Parameter estimates for the GBM models featured lower drift and higher volatility terms under phase four (Table 3) and have resulted in an increase in the trigger price at which immediate retrofits of CCS is optimal. The results of the GBM models would suggest that despite the higher starting carbon price, the pricing signal of future EUA price paths has decreased since the publication of Abadie and Chamorro (2008) and CCS technology has become less viable as an emission abatement option.

Expanding the stochastic modelling assumption of carbon prices from a one-factor GBM model to the two-factor STLT model substantially affected valuation estimates, investment trigger prices and the probability of investment over the lifetime of the SCPC unit (Figure 3). Modelling carbon prices through a two-factor model has notably increased the strength of the carbon pricing signal under phase four, with the estimated NPV of the project almost tripling and the EUA trigger price decreasing by approximately $24 \%$. Estimated project values with the STLT model under phase two decreased project value and increased trigger prices in comparison to the GBM model. Investment decisions under the GBM models were identical within $0.3 \%$ within the first fifteen years of the power plants lifetime despite the lower estimated drift term and higher initial carbon price under phase four. Modelling EUAs with the STLT model has increased the probability of investment by $3.46 \%$ under phase two and $9.39 \%$ under phase four. Modelling EUAs with the STLT model has had a two-tailed effect upon trigger prices and project value under phase two and four, suggesting that the effect of increasing the complexity of EUA modelling through additional factors on valuation estimates cannot be explained by the introduction of downward or upward bias.

\section{***Insert Figure 3 approximately here***}

Figure 3. Proportion of invested paths over the forecasting horizon

The extreme length of the forecasting horizon (40 years) within this case study has resulted in high standard errors for the NPV and ROV. Forecasting projects beyond 40 years is unlikely when performing ROA and thus these standard errors can be considered to be at their highest. Increasing the dimensions of the EUA stochastic model has increased standard errors for the NPV and ROV under phase four, however, the WOV to delay investment and corresponding investment trigger price, being the difference between the ROV and NPV, is calculated with a higher level of precision. Therefore an increase in the dimensionality of the problem has not decreased the uncertainty of the estimated value of the option to delay investment and corresponding optimal investment decisions.

LSM Simulation is the recommended ROA solution method when valuing projects under carbon pricing uncertainty due to the multi-dimensional STLT stochastic model used and the curse of dimensionality prohibiting efficient valuation within a lattice framework. The two-dimensional binomial lattice solved by Abadie and Chamorro (2008) further required an analytic expression for the NPV of annuities under a GBM and inhomogeneous GBM stochastic process, whilst a closed-form expression for the present value of an annuity that follows the STLT stochastic process does not exist. The LSM Simulation 
solution method further allows for greater analysis of investment performance measures (Table 7), such as the expected sequestered emissions resulting from this investment decision under existing carbon pricing signals. This metric is of importance to EUA policy setters, as it estimates the reduction in emissions in response to existing climate-policy pricing signals. Applying this metric to a portfolio of abatement options can provide climate-policy regulators with estimates to future emission abatement.

\section{***Insert table 7 approximately here ${ }^{* * *}$}

Figure 4 displays a replication of Figure 5 from the work of Abadie and Chamorro (2008), with output trigger prices from this study included. Following the work of Abadie and Chamorro (2008), the trigger price of investment increases steeply for power plants with a remaining useful life below 8 years, with comparable trigger prices for each of the different stochastic models and ROA solution methods. Trigger prices under phase four through GBM modelling are comparable with those found within the initial work of Abadie and Chamorro (2008). However, extending the stochastic model to the STLT model has greatly decreased these trigger prices.

\section{***Insert figure 4 approximately here ${ }^{* * *}$}

Figure 4. Investment and no-investment regions depending on useful life

The ongoing progression of research and development into CCS technology means that the financial parameters of the original CCS retrofit case study may have changed substantially since their publication, warranting a sensitivity analysis of key variables to the value of retrofitting CCS and associated trigger prices. Following the work of Abadie and Chamorro (2008), it is assumed that the power plant has a residual lifetime of 30 years for sensitivity analysis purposes. Outputs of sensitivity analysis of this case study are in line with major findings found within the literature that have performed ROA to value CCS retrofits.

\section{***Insert table 8 approximately here $* * *$}

Parameter estimates for wholesale electricity prices have been assumed constant for this case study, while in reality, these parameters are likely to change over time and depending on geographic location, highly influencing calculated project value and trigger prices (Table 8).

\section{***Insert table 9 approximately here ***}

Decreases to the initial capital expenditure of CCS retrofits can increase the propensity to invest within the technology (Table 9), making technology investment subsidies a possible method of increasing the commercial uptake of this emission abatement option (Abadie and Chamorro, 2008; Wang and Du, 2016; Zhang et al., 2014). Immediate investment into CCS retrofits is sup-optimal even with a $100 \%$ investment subsidy, suggesting that energy producers feature a low willingness to capture emissions even after retrofits (Zhang et al., 2014; Zhu and Fan, 2013).

\section{***Insert table 10 approximately here *** \\ ***Insert table 11 approximately here ***}

Changes in the operational costs (Table 10) and energy efficiency penalty (Table 11) of transporting and storing (T\&S) $\mathrm{CO}_{2}$ has a greater effect on project value than changes to capital expenditure, although subsidies on captured emissions would be much higher, suggesting that there is little likelihood of governments introducing capture subsidies (Zhu and Fan, 2011, 2013).

$$
\text { ***Insert table } 12 \text { approximately here } * * *
$$

Increases to the construction time of CCS units can negatively influence trigger prices (Table 12), particularly if energy production of the SCPC plant must be halted during this construction phase. 


\section{Conclusion:}

This study has evaluated the ability of one-factor and two-factor models to explain the term structure of the EU ETS and the value of the option to retrofit CCS technology under these models. The twofactor STLT model of Schwartz and Smith (2000) was empirically determined to possess a better fit than popular one-factor models at a $0.1 \%$ level of statistical significance to observed futures contracts that expired within phases two and four of the EUA carbon market. Compared with GBM model parameters, the STLT model featured higher drift and lower volatility terms for the random-walk factor, suggesting that $4-5 \%$ of the volatility of EUAs can be explained through a separate factor with minimal mean-reversion and very low correlation to the random-walk factor.

Estimated stochastic models were used to replicate and extend the CCS retrofit case study first presented by Abadie and Chamorro (2008). It was demonstrated that the stochastic process used to forecast EUA spot prices has a large impact on the calculated project value and critical values at which immediate investment is optimal. Immediate investment in the retrofitting of CCS is not optimal under either phase of the EU ETS. Modelling EUAs through a GBM model leads to the conclusion that the pricing signals generated by the market have decreased in relation to phase two estimates. In contrast, the STLT model greatly increases the strength of this signal, such that current signals in conjunction with market high existing price levels create the strongest pressure to reduce emissions under the EU ETS since market inception. Reforms implemented to address the problem of overabundance of allowances in the market has substantially strengthened the carbon pricing signal.

Future research opportunities include applying our phase four models to value alternate emission abatement technologies, such as renewable energies or other carbon sequestration technologies, with contemporary financial estimates. Further, the use of contemporary parameter estimates for wholesale electricity prices would provide further insights into the commercial viability of CCS technology and the correlation between different factors of the carbon price and electricity prices. The work of Cortazar and Naranjo (2006) presents an $\mathrm{N}$-factor stochastic model to describe the term structure of commodities, of which the model of Schwartz and Smith (2000) is a special case when $N=2$. Extending the stochastic modelling of carbon prices into an $\mathrm{N}$-factor framework or expanding the Kalman Filter methodology by accounting for non-linearity in the transition equations or relaxed assumptions of a Gaussian residual term, is a natural methodological extension. Extending the Real Options framework to allow for the exercise of operational flexibilities, such as temporary suspension or permanent abandonment, of the CCS project could decrease the irreversibility of this project and promote CCS retrofits. Applying the two-factor STLT model within this framework may affect the value of shortterm real options made under uncertainty due to the additional information captured by the stochastic model over one-factor models, reducing the effect of hysteresis on the values of these Real Options.

\section{References}

Abadie, L. M., and J. M. Chamorro, 2008, European CO2 prices and carbon capture investments. Energy Economics, 30, 2992-3015.

Abadie, L. M., I. Galarraga, and D. Rübbelke, 2014, Evaluation of two alternative carbon capture and storage technologies: A stochastic model. Environmental modelling software, 54, 182-195. 
Abadíe, L. M., 2007, Energy assets valuation a real options application. Universidad del País VascoEuskal Herriko Unibertsitatea,

Abramowitz, M., and I. A. Stegun. 1965, Handbook of mathematical functions: with formulas, graphs, and mathematical tables, Vol. 55 (US Government printing office).

Blyth, W., R. Bradley, D. Bunn, C. Clarke, T. Wilson, and M. Yang, 2007, Investment risks under uncertain climate change policy. Energy Policy, 35, 5766-5773.

Chevallier, J., 2009, Carbon futures and macroeconomic risk factors: a view from the EU ETS. Energy Economics, 31, 614-625.

Clara, S. D., and K. Mayr. 2018. The EU ETS phase IV reform: implications for system functioning and for the carbon price signal. Available at: https://www.oxfordenergy.org/wpcms/wpcontent/uploads/2018/09/The-EU-ETS-phase-IV-reform-implications-for-system-functioningand-for-the-carbon-price-signal-Insight-38.pdf?v=7516fd43adaa

Compernolle, T., K. Welkenhuysen, K. Huisman, K. Piessens, and P. Kort, 2017, Off-shore enhanced oil recovery in the North Sea: The impact of price uncertainty on the investment decisions. Energy Policy, 101, 123-137.

Cortazar, G., and L. Naranjo, 2006, An N-factor Gaussian model of oil futures prices. Journal of Futures Markets: Futures, Options, and Other Derivative Products, 26, 243-268.

Daskalakis, G., D. Psychoyios, and R. N. Markellos, 2009, Modeling CO2 emission allowance prices and derivatives: Evidence from the European trading scheme. Journal of Banking \& Finance, $33,1230-1241$.

Ellerman, A. D., F. J. Convery, C. d. Perthuis, E. Alberola, B. K. Buchner, A. Delbosc, . . F. Matthes. 2010, Pricing Carbon: The European Union Emissions Trading Scheme. (Cambridge University Press, Cambridge).

European Commission, 2020, EU Emissions Trading System (EU ETS) - Revision for Phase 4 (20212030). Available at: https://ec.europa.eu/clima/policies/ets/revision_en

Fan, J. L., S. J. Wei, L. Yang, H. Wang, P. Zhong, and X. Zhang, 2019, Comparison of the LCOE between coal-fired power plants with CCS and main low-carbon generation technologies: Evidence from China. Energy, 176, 143-155.

This is the peer reviewed version of the following article: Aspinall, T., Gepp, A., Harris, G., Kelly, S., Southam, C., \& Vanstone, B. J. (2020). Estimation of a Term Structure Model of Carbon Prices through State Space Methods: The European Union Emissions Trading Scheme. Accounting and Finance., which has been published in final form at https://doi.org/10.1111/acfi.12708. 
Fuss, S., J. Szolgayová, M. Obersteiner, and M. Gusti, 2008, Investment under market and climate policy uncertainty. Applied Energy, 85, 708-721.

Gibson, R., and E. S. Schwartz, 1990, Stochastic Convenience Yield and the Pricing of Oil Contingent Claims. The Journal of Finance, 45, 959-976.

Glasserman, P., 2004, Monte Carlo methods in financial engineering, 2nd ed. Vol. 53 (Springer Science \& Business Media, New York).

Hauck, D., and A. F. Hof, 2017, Abandonment of natural gas production and investment in carbon storage. Energy Policy, 108, 322-329.

Heydari, S., N. Ovenden, and A. Siddiqui, 2010, Real options analysis of investment in carbon capture and sequestration technology. Computational Management Science, 9, 109-138.

Hintermann, B., S. Peterson, and W. Rickels, 2016, Price and Market Behavior in Phase II of the EU ETS: A Review of the Literature. Review of environmental economics and policy, 10, 108-128.

Intergovernmental Panel on Climate Change (IPCC). (2005). Carbon Dioxide Capture And Storage. Available at: https://www.ipcc.ch/report/carbon-dioxide-capture-and-storage/

Kalman, R. E., 1960, A new approach to linear filtering and prediction problems.

Knoope, M. M. J., A. Ramírez, and A. P. C. Faaij, 2015a, The influence of uncertainty in the development of a CO2 infrastructure network. Applied Energy, 158, 332-347.

Knoope, M. M. J., A. Ramírez, and A. P. C. Faaij, 2015b, Investing in CO2 transport infrastructure under uncertainty: A comparison between ships and pipelines. International Journal of Greenhouse Gas Control, 41, 174-193.

Laude, A., and C. Jonen, 2013, Biomass and CCS: The influence of technical change. Energy Policy, 60, 916-924.

Laurikka, H., and T. Koljonen, 2006, Emissions trading and investment decisions in the power sectora case study in Finland. Energy Policy, 34, 1063-1074.

Lautier, D., and A. Galli, 2004, Simple and extended Kalman filters: an application to term structures of commodity prices. Applied Financial Economics, 14, 963-973.

Li, J., Y. Hou, P. Wang, and B. Yang, 2019, A Review of Carbon Capture and Storage Project Investment and Operational Decision-Making Based on Bibliometrics. Energies, 12, 23. 
Longstaff, F. A., and E. S. Schwartz, 2001, Valuing American Options by Simulation: A Simple LeastSquares Approach. The Review of Financial Studies, 14, 113-147.

Mebane Jr, W. R., and J. S. Sekhon, 2011, Genetic optimization using derivatives: the rgenoud package for R. Journal of Statistical Software, 42, 1-26.

Mo, J.-L., J. Schleich, and Y. Fan, 2018, Getting ready for future carbon abatement under uncertainty - Key factors driving investment with policy implications. Energy Economics, 70, 453-464.

Mo, J.-L., J. Schleich, L. Zhu, and Y. Fan, 2015, Delaying the introduction of emissions trading systems - Implications for power plant investment and operation from a multi-stage decision model. Energy Economics, 52, 255-264.

Mo, J.-L., and L. Zhu, 2014, Using floor price mechanisms to promote carbon capture and storage (CCS) investment and CO2 abatement. Energy \& Environment, 25, 687-707.

Pindyck, R. S., 2013, Pricing Carbon When We Don't Know The Right Price. Regulation, 36, 43-46.

Rammerstorfer, M., and R. Eisl, 2011, Carbon capture and storage-Investment strategies for the future? Energy Policy, 39, 7103-7111.

Reinelt, P. S., and D. W. Keith, 2007, Carbon capture retrofits and the cost of regulatory uncertainty. The Energy Journal, 28, 101-128.

Rohlfs, W., and R. Madlener, 2011, Valuation of CCS-ready coal-fired power plants: a multidimensional real options approach. Energy Systems, 2, 243-261.

Rubin, E. S., 2012, Understanding the pitfalls of CCS cost estimates. International Journal of Greenhouse Gas Control, 10, 181-190.

Sauvageau, M., and M. Kumral, 2018, Genetic algorithms for the optimisation of the Schwartz-Smith two-factor model: a case study on a copper deposit. International Journal of Mining, Reclamation and Environment, 32, 163-181.

Schwartz, E. S., 1997, The Stochastic Behavior of Commodity Prices: Implications for Valuation and Hedging. The Journal of Finance, 52, 923-973.

Schwartz, E. S., 1998, Valuing long-term commodity assets. Financial Management, 57-66.

Schwartz, E. S., 2013, The Real Options Approach to Valuation: Challenges and Opportunities. Latin American Journal of Economics, 50, 163-177.

This is the peer reviewed version of the following article: Aspinall, T., Gepp, A., Harris, G., Kelly, S., Southam, C., \& Vanstone, B. J. (2020). Estimation of a Term Structure Model of Carbon Prices through State Space Methods: The European Union Emissions Trading Scheme. Accounting and Finance., which has been published in final form at https://doi.org/10.1111/acfi.12708.

This article may be used for non-commercial purposes in accordance with Wiley Terms and Conditions for Use of Self-Archived Versions. 
Schwartz, E. S., and J. E. Smith, 2000, Short-Term Variations and Long-Term Dynamics in Commodity Prices. Manage. Sci., 46, 893-911.

Szolgayova, J., S. Fuss, and M. Obersteiner, 2008, Assessing the effects of CO2 price caps on electricity investments-A real options analysis. Energy Policy, 36, 3974-3981.

Walsh, D., K. O'Sullivan, W. Lee, and M. Devine, 2014, When to invest in carbon capture and storage technology: A mathematical model. Energy Economics, 42, 219-225.

Wang, X., and L. Du, 2016, Study on carbon capture and storage (CCS) investment decision-making based on real options for China's coal-fired power plants. Journal of Cleaner Production, 112, 4123-4131.

World Bank Group, 2014, State and Trends of Carbon Pricing 2014 (May). Available at: https://openknowledge.worldbank.org/

World Bank Group, 2016, State and Trends of Carbon Pricing 2016 (October). Available at: https://openknowledge.worldbank.org/

Yu, H., Y.-M. Wei, B.-J. Tang, Z. Mi, and S.-Y. Pan, 2016, Assessment on the research trend of lowcarbon energy technology investment: A bibliometric analysis. Applied Energy, 184, 960-970.

Zhang, X., X. Wang, J. Chen, X. Xie, K. Wang, and Y. Wei, 2014, A novel modeling based real option approach for CCS investment evaluation under multiple uncertainties. Applied Energy, 113, 1059-1067.

Zhou, W., B. Zhu, D. Chen, F. Zhao, and W. Fei, 2014, How policy choice affects investment in lowcarbon technology: The case of $\mathrm{CO} 2$ capture in indirect coal liquefaction in China. Energy, 73, 670-679.

Zhou, W., B. Zhu, S. Fuss, J. Szolgayová, M. Obersteiner, and W. Fei, 2010, Uncertainty modeling of CCS investment strategy in China's power sector. Applied Energy, 87, 2392-2400.

Zhu, L., and Y. Fan, 2011, A real options-based CCS investment evaluation model: Case study of China's power generation sector. Applied Energy, 88, 4320-4333.

Zhu, L., and Y. Fan, 2013, Modelling the investment in carbon capture retrofits of pulverized coal-fired plants. Applied Energy, 57, 66-75.

This is the peer reviewed version of the following article: Aspinall, T., Gepp, A., Harris, G., Kelly, S., Southam, C., \& Vanstone, B. J. (2020). Estimation of a Term Structure Model of Carbon Prices through State Space Methods: The European Union Emissions Trading Scheme. Accounting and Finance., which has been published in final form at https://doi.org/10.1111/acfi.12708.

This article may be used for non-commercial purposes in accordance with Wiley Terms and Conditions for Use of Self-Archived Versions. 
This is the peer reviewed version of the following article: Aspinall, T., Gepp, A., Harris, G., Kelly, S., Southam, C., \& Vanstone, B. J. (2020). Estimation of a Term Structure Model of Carbon Prices through State Space Methods: The European Union Emissions Trading Scheme. Accounting and Finance., which has been published in final form at https://doi.org/10.1111/acfi.12708.

This article may be used for non-commercial purposes in accordance with Wiley Terms and Conditions for Use of Self-Archived Versions. 


\begin{tabular}{|c|c|c|c|c|}
\hline Dataset Name & Start Date & End Date & Observations & Maturities \\
\hline $\begin{array}{c}\text { Phase Two } \\
\text { (Abadie and Chamorro, 2008) }\end{array}$ & $01 / 05 / 2006$ & $10 / 5 / 2007$ & 265 & $\operatorname{Dec}\{08-12\}$ \\
\hline Phase Four & $2 / 01 / 2018$ & $28 / 07 / 2020$ & 661 & $\{0.25,0.5,1,1.5,1.75\}$ \\
\hline
\end{tabular}

Table 1. Description of phase two replication and phase four futures data 


\begin{tabular}{|c|c|c|}
\hline & Phase Two & Phase Four \\
\hline $\begin{array}{c}\text { Geometric Ornstein-Uhlenbeck } \\
\text { (MR) }\end{array}$ & 4,682 & 8,985 \\
\hline $\begin{array}{c}\text { Geometric Brownian Motion } \\
\text { (GBM) }\end{array}$ & 4,674 & 12,129 \\
\hline $\begin{array}{c}\text { Short-Term/Long-Term Model } \\
\text { (STLT) }\end{array}$ & 5,505 & 15,320 \\
\hline
\end{tabular}

Table 2 Log-Likelihood Scores for Model Comparison

This is the peer reviewed version of the following article: Aspinall, T., Gepp, A., Harris, G., Kelly, S., Southam, C., \& Vanstone, B. J. (2020). Estimation of a Term Structure Model of Carbon Prices through State Space Methods: The European Union Emissions Trading Scheme. Accounting and Finance., which has been published in final form at https://doi.org/10.1111/acfi.12708.

This article may be used for non-commercial purposes in accordance with Wiley Terms and Conditions for Use of Self-Archived Versions. 


\begin{tabular}{|c|c|c|c|c|c|c|}
\hline & \multirow{2}{*}{$\begin{array}{c}\text { Abadie } \\
\text { and } \\
\text { Chamorro } \\
\text { (2008) }\end{array}$} & \multirow[b]{2}{*}{ Replication } & \multicolumn{2}{|c|}{ Phase Two } & \multicolumn{2}{|c|}{ Phase Four } \\
\hline & & & GBM & STLT & GBM & STLT \\
\hline$\alpha_{\xi}$ & - & $\begin{array}{c}0.1741 \\
(0.4675)\end{array}$ & $\begin{array}{c}0.0189 \\
(0.4783)\end{array}$ & $\begin{array}{c}0.1361 \\
(0.4497)\end{array}$ & $\begin{array}{c}0.4583 \\
(0.3310)\end{array}$ & $\begin{array}{c}0.4973 \\
(0.3024)\end{array}$ \\
\hline$\alpha_{\xi}-\lambda_{\xi}$ & 0.0308 & $\begin{array}{c}0.0308 \\
(0.0001)\end{array}$ & $\begin{array}{c}0.0306 \\
(0.0001)\end{array}$ & $\begin{array}{c}0.0365 \\
(0.0003)\end{array}$ & $\begin{array}{c}0.0115 \\
(0.0001)\end{array}$ & $\begin{array}{c}0.0446 \\
(0.0030)\end{array}$ \\
\hline$\sigma_{\xi}$ & 0.4683 & $\begin{array}{c}0.4731 \\
(0.0208)\end{array}$ & $\begin{array}{c}0.4845 \\
(0.0210) \\
\end{array}$ & $\begin{array}{c}0.4401 \\
(0.0215)\end{array}$ & $\begin{array}{c}0.5307 \\
(0.0145)\end{array}$ & $\begin{array}{c}0.5077 \\
(0.0141)\end{array}$ \\
\hline$\kappa$ & - & - & - & $\begin{array}{c}0.1792 \\
(0.0005)\end{array}$ & - & $\begin{array}{c}0.2462 \\
(0.0184)\end{array}$ \\
\hline$\lambda_{\chi}$ & - & - & - & $\begin{array}{c}0.0443 \\
(0.0063) \\
\end{array}$ & - & $\begin{array}{c}0.0622 \\
(0.0045)\end{array}$ \\
\hline$\sigma_{\chi}$ & - & - & - & $\begin{array}{c}0.2059 \\
(0.0005) \\
\end{array}$ & - & $\begin{array}{c}0.0748 \\
(0.0050) \\
\end{array}$ \\
\hline$\rho_{\chi \xi}$ & - & - & - & $\begin{array}{c}0.0091 \\
(0.0595) \\
\end{array}$ & - & $\begin{array}{c}0.2960 \\
(0.0420) \\
\end{array}$ \\
\hline$s_{1}$ & & & $\begin{array}{c}0.0081 \\
(0.0003)\end{array}$ & $\begin{array}{c}0.0033 \\
(0.0001)\end{array}$ & $\begin{array}{c}0.0021 \\
(0.0001)\end{array}$ & 0 \\
\hline$s_{2}$ & & & $\begin{array}{c}0.0036 \\
(0.0001)\end{array}$ & $\begin{array}{c}0.0015 \\
(0.0002)\end{array}$ & 0 & $\begin{array}{c}0.0008 \\
(0.0001)\end{array}$ \\
\hline$s_{3}$ & 0.0056 & $\begin{array}{c}0.0056 \\
(0.0002)\end{array}$ & 0 & $\begin{array}{c}0.0005 \\
(0.0002)\end{array}$ & $\begin{array}{c}0.0030 \\
(0.0001)\end{array}$ & $\begin{array}{c}0.0013 \\
(0.0001)\end{array}$ \\
\hline$S_{4}$ & & & $\begin{array}{c}0.0034 \\
(0.0034)\end{array}$ & $\begin{array}{c}0.0016 \\
(0.0003)\end{array}$ & $\begin{array}{c}0.0060 \\
(0.0001)\end{array}$ & $\begin{array}{c}0.0005 \\
(0.0002)\end{array}$ \\
\hline$S_{5}$ & & & $\begin{array}{c}0.0066 \\
(0.0066)\end{array}$ & $\begin{array}{c}0.0036 \\
(0.0005)\end{array}$ & $\begin{array}{c}0.0076 \\
(0.0002)\end{array}$ & $\begin{array}{c}0.0017 \\
(0.0001)\end{array}$ \\
\hline
\end{tabular}

Table 3. Maximum-Likelihood Parameter Estimates of panel data. Standard errors of estimates are given in brackets 


\begin{tabular}{|l|l|l|}
\hline \multicolumn{1}{|c|}{ Parameter } & \multicolumn{1}{c|}{ Unit } & \multicolumn{1}{c|}{ Value } \\
\hline SCPC remaining lifetime & Years & 40 \\
\hline Construction period & Years & 1 \\
\hline Initial capital expenditure & $\mathrm{M} €$ & 214.5 \\
\hline Learning rate & $\% /$ year & 2.02 \\
\hline SCPC initial output & $\mathrm{GWh}$ & 3,504 \\
\hline Ancillary unit output penalty & $\%$ & $5 \%$ \\
\hline CCS unit output penalty & $\%$ & $15 \%$ \\
\hline $\begin{array}{l}\text { CCS operation and maintenance } \\
\text { costs }\end{array}$ & $€ /$ MWh p.a. & 1.348 \\
\hline Captured $\mathrm{CO}_{2}$ Emissions & $\mathrm{tCO}_{2} /$ year & $2,396,736$ \\
\hline CCS transport and storage costs & $€ / \mathrm{tCO}_{2}$ & 7.32 \\
\hline
\end{tabular}

Table 4. Financial Parameters of a Super Critical Pulverized Coal Power Plant

This is the peer reviewed version of the following article: Aspinall, T., Gepp, A., Harris, G., Kelly, S., Southam, C., \& Vanstone, B. J. (2020). Estimation of a Term Structure Model of Carbon Prices through State Space Methods: The European Union Emissions Trading Scheme. Accounting and Finance., which has been published in final form at https://doi.org/10.1111/acfi.12708. 


\begin{tabular}{|l|l|l|}
\hline \multicolumn{1}{|c|}{ Description } & \multicolumn{1}{c|}{ Parameter } & \multicolumn{1}{c|}{ Value } \\
\hline Initial Price & $E_{0}$ & 0.04083 \\
\hline Equilibrium Price & $L_{e}$ & 0.037852 \\
\hline Reversion Rate & $k_{e}$ & 0.9604 \\
\hline Instantaneous Volatility & $\sigma_{e}$ & 0.4968 \\
\hline Correlation in commodities & $\rho_{c, e}$ & 0.2738 \\
\hline
\end{tabular}

Table 5. Wholesale Electricity stochastic modelling parameters

This is the peer reviewed version of the following article: Aspinall, T., Gepp, A., Harris, G., Kelly, S., Southam, C., \& Vanstone, B. J. (2020). Estimation of a Term Structure Model of Carbon Prices through State Space Methods: The European Union Emissions Trading Scheme. Accounting and Finance., which has been published in final form at https://doi.org/10.1111/acfi.12708.

This article may be used for non-commercial purposes in accordance with Wiley Terms and Conditions for Use of Self-Archived Versions. 


\begin{tabular}{|c|c|c|c|c|c|c|}
\hline & \multirow{2}{*}{$\begin{array}{c}\text { Abadie and } \\
\text { Chamorro } \\
(2008)\end{array}$} & \multirow{2}{*}{ Replication } & \multicolumn{2}{|c|}{ Phase Two } & \multicolumn{2}{|c|}{ Phase Four } \\
\hline & & & GBM & STLT & GBM & STLT \\
\hline $\begin{array}{l}\text { NPV } \\
(\mathrm{M} €)\end{array}$ & 262.02 & $\begin{array}{l}267.43 \\
{[18.95]}\end{array}$ & $\begin{array}{l}265.31 \\
{[20.72]}\end{array}$ & $\begin{array}{l}171.78 \\
{[15.8]}\end{array}$ & $\begin{array}{l}293.37 \\
{[22.15]}\end{array}$ & $\begin{array}{l}856.74 \\
{[43.63]}\end{array}$ \\
\hline $\begin{array}{l}\text { ROV } \\
(\mathrm{M} €)\end{array}$ & 606.53 & $\begin{array}{l}632.99 \\
{[18.77]}\end{array}$ & $\begin{array}{l}641.95 \\
{[20.56]}\end{array}$ & $\begin{array}{l}548.73 \\
{[15.61]}\end{array}$ & $\begin{array}{l}642.57 \\
{[22.00]}\end{array}$ & $\begin{array}{c}1,122.38 \\
{[43.52]}\end{array}$ \\
\hline $\begin{array}{l}\text { WOV } \\
(\mathrm{M} €)\end{array}$ & 344.49 & $\begin{array}{l}363.44 \\
{[1.42]}\end{array}$ & $\begin{array}{c}376.64 \\
{[1.44]}\end{array}$ & $\begin{array}{l}376.95 \\
{[1.32]}\end{array}$ & $\begin{array}{l}349.20 \\
{[1.54]}\end{array}$ & $\begin{array}{l}265.65 \\
{[1.73]}\end{array}$ \\
\hline $\begin{array}{l}\text { NPV Trigger } \\
\text { Price } \\
\left(€ / \mathrm{tCO}_{2} \mathrm{e}\right)\end{array}$ & 13.95 & 13.87 & 13.92 & 15.68 & 19.31 & 13.15 \\
\hline $\begin{array}{c}\text { ROA Trigger } \\
\text { Price } \\
\left(€ / \mathrm{tCO}_{2} \mathrm{e}\right)\end{array}$ & 54.09 & 41.79 & 41.56 & 43.52 & 54.71 & 44.02 \\
\hline
\end{tabular}

Table 6. Calculated Project Value of the option to retrofit CCS technology under different phases of the EU ETS. Standard errors of estimates are given in square brackets. 


\begin{tabular}{|c|c|c|c|c|}
\hline \multirow{2}{*}{} & \multicolumn{2}{|c|}{ Phase Two } & \multicolumn{2}{c|}{ Phase Four } \\
\cline { 2 - 5 } & GBM & STLT & GBM & STLT \\
\hline $\begin{array}{c}\text { Proportion of } \\
\text { Invested Paths }\end{array}$ & $17.97 \%$ & $21.43 \%$ & $14.52 \%$ & $23.91 \%$ \\
\hline $\begin{array}{c}\text { Expected } \\
\text { Investment Time }\end{array}$ & 10.52 Years & 11.24 Years & 8.27 Years & 9.73 Years \\
\hline $\begin{array}{c}\text { Expected Payback } \\
\text { Period }\end{array}$ & 8.57 Years & 8.79 Years & 7.35 Years & 7.95 Years \\
\hline $\begin{array}{c}\text { Expected } \\
\text { Sequestered } \\
\text { Emissions }\end{array}$ & $68.27 \mathrm{MtCO}_{2} \mathrm{e}$ & $66.54 \mathrm{MtCO}_{2} \mathrm{e}$ & $73.66 \mathrm{MtCO}_{2} \mathrm{e}$ & $70.15 \mathrm{MtCO}_{2} \mathrm{e}$ \\
\hline
\end{tabular}

Table 7. Simulation Investment Characteristics 


\begin{tabular}{|c|c|c|c|c|c|}
\hline \multirow{2}{*}{$\begin{array}{c}L_{e} \text { (cents } \\
€ / \mathrm{kWh})\end{array}$} & \multirow{2}{*}{$\begin{array}{c}\text { Abadie and } \\
\text { Chamorro } \\
(2008)\end{array}$} & \multicolumn{2}{|c|}{ Phase Two } & \multicolumn{2}{|c|}{ Phase Four } \\
\hline & & GBM & STLT & GBM & STLT \\
\hline $\begin{array}{l}1.8926 \\
(-50 \%)\end{array}$ & - & $\begin{array}{c}486.80 \mathrm{M} € \\
(+6.10 \%) \\
{\left[35.48 € / \mathrm{tCO}_{2} \mathrm{e}\right]}\end{array}$ & $\begin{array}{c}420.38 \mathrm{M} € \\
(+7.50 \%) \\
{\left[36.48 € / \mathrm{tCO}_{2} \mathrm{e}\right]}\end{array}$ & $\begin{array}{c}542.40 \mathrm{M} € \\
(+5.90 \%) \\
{\left[44.92 € / \mathrm{tCO}_{2} \mathrm{e}\right]}\end{array}$ & $\begin{array}{c}845.81 \mathrm{M} € \\
(+4.25 \%) \\
{\left[37.37 € / \mathrm{tCO}_{2} \mathrm{e}\right]}\end{array}$ \\
\hline $\begin{array}{l}3.0282 \\
(-20 \%)\end{array}$ & {$\left[50.76 € / \mathrm{tCO}_{2} \mathrm{e}\right]$} & $\begin{array}{c}469.01 \mathrm{M} € \\
(+2.20 \%) \\
{\left[39.88 € / \mathrm{tCO}_{2} \mathrm{e}\right]}\end{array}$ & $\begin{array}{c}401.97 \mathrm{M} € \\
(+2.80 \%) \\
{\left[40.80 € / \mathrm{tCO}_{2} \mathrm{e}\right]}\end{array}$ & $\begin{array}{c}522.56 \mathrm{M} € \\
(+2.10 \%) \\
{\left[50.52 € / \mathrm{tCO}_{2} \mathrm{e}\right]}\end{array}$ & $\begin{array}{c}820.18 \mathrm{M} € \\
(+1.09 \%) \\
{\left[41.81 € / \mathrm{tCO}_{2} \mathrm{e}\right]}\end{array}$ \\
\hline $\begin{array}{l}3.4067 \\
(-10 \%)\end{array}$ & {$\left[52.57 € / \mathrm{tCO}_{2} \mathrm{e}\right]$} & $\begin{array}{c}463.41 \mathrm{M} € \\
(+1.00 \%) \\
{\left[41.36 € / \mathrm{tCO}_{2} \mathrm{e}\right]}\end{array}$ & $\begin{array}{c}396.55 \mathrm{M} € \\
(+1.40 \%) \\
{\left[42.30 € / \mathrm{tCO}_{2} \mathrm{e}\right]}\end{array}$ & $\begin{array}{c}516.46 \mathrm{M} € \\
(+0.90 \%) \\
{\left[52.40 € / \mathrm{tCO}_{2} \mathrm{e}\right]}\end{array}$ & $\begin{array}{c}812.68 \mathrm{M} € \\
(+0.16 \%) \\
{\left[43.40 € / \mathrm{tCO}_{2} \mathrm{e}\right]}\end{array}$ \\
\hline 3.7852 & {$\left[54.51 € / \mathrm{tCO}_{2} \mathrm{e}\right]$} & $\begin{array}{c}458.72 \mathrm{M} € \\
{\left[42.99 € / \mathrm{tCO}_{2} \mathrm{e}\right]}\end{array}$ & $\begin{array}{c}391.09 \mathrm{M} € \\
{\left[44.34 € / \mathrm{tCO}_{2} \mathrm{e}\right]}\end{array}$ & $\begin{array}{c}512.00 \mathrm{M} € \\
{\left[54.61 € / \mathrm{tCO}_{2} \mathrm{e}\right]}\end{array}$ & $\begin{array}{c}811.36 \mathrm{M} € \\
{\left[45.52 € / \mathrm{tCO}_{2} \mathrm{e}\right]}\end{array}$ \\
\hline $\begin{array}{c}4.1637 \\
(+10 \%)\end{array}$ & {$\left[56.29 € / \mathrm{tCO}_{2} \mathrm{e}\right]$} & $\begin{array}{c}453.47 \mathrm{M} € \\
(-1.10 \%) \\
{\left[44.33 € / \mathrm{CCO}_{2} \mathrm{e}\right]}\end{array}$ & $\begin{array}{c}385.96 \mathrm{M} € \\
(-1.30 \%) \\
{\left[45.21 € / \mathrm{tCO}_{2} \mathrm{e}\right]}\end{array}$ & $\begin{array}{c}505.55 \mathrm{M} € \\
(-1.30 \%) \\
{\left[56.16 € / \mathrm{tCO}_{2} \mathrm{e}\right]}\end{array}$ & $\begin{array}{c}797.80 \mathrm{M} € \\
(-1.67 \%) \\
{\left[46.41 € / \mathrm{tCO}_{2} \mathrm{e}\right]}\end{array}$ \\
\hline $\begin{array}{c}4.5422 \\
(+20 \%)\end{array}$ & {$\left[58.28 € / \mathrm{tCO}_{2} \mathrm{e}\right]$} & $\begin{array}{c}448.77 \mathrm{M} € \\
(-2.20 \%) \\
{\left[45.81 € / \mathrm{tCO}_{2} \mathrm{e}\right]}\end{array}$ & $\begin{array}{c}381.05 \mathrm{M} € \\
(-2.60 \%) \\
{\left[46.66 € / \mathrm{tCO}_{2} \mathrm{e}\right]}\end{array}$ & $\begin{array}{c}500.38 \mathrm{M} € \\
(-2.30 \%) \\
{\left[58.04 € / \mathrm{tCO}_{2} \mathrm{e}\right]}\end{array}$ & $\begin{array}{c}790.31 \mathrm{M} € \\
(-2.59 \%) \\
{\left[47.90 € / \mathrm{tCO}_{2} \mathrm{e}\right]}\end{array}$ \\
\hline $\begin{array}{c}5.6778 \\
(+50 \%)\end{array}$ & - & $\begin{array}{c}434.82 \mathrm{M} € \\
(-5.20 \%) \\
{\left[50.22 € / \mathrm{tCO}_{2} \mathrm{e}\right]}\end{array}$ & $\begin{array}{c}366.89 \mathrm{M} € \\
(-6.20 \%) \\
{\left[51.01 € / \mathrm{tCO}_{2} \mathrm{e}\right]}\end{array}$ & $\begin{array}{c}485.58 \mathrm{M} € \\
(-5.20 \%) \\
{\left[63.64 € / \mathrm{tCO}_{2} \mathrm{e}\right]}\end{array}$ & $\begin{array}{c}769.46 \mathrm{M} € \\
(-5.16 \%) \\
{\left[52.39 € / \mathrm{tCO}_{2} \mathrm{e}\right]}\end{array}$ \\
\hline
\end{tabular}

Table 8. Calculated Real Option Value and investment trigger price as a function of Equilibrium Electricity Price. Percentage changes in ROV are shown in brackets, and investment trigger prices are shown in square brackets. 


\begin{tabular}{|c|c|c|c|c|}
\hline \multirow{2}{*}{$\boldsymbol{C A P E} \boldsymbol{X}$} & \multicolumn{2}{|c|}{ Phase Two } & \multicolumn{2}{c|}{ Phase Four } \\
\cline { 2 - 5 } & GBM & STLT & GBM & STLT \\
\hline 0 & $504.47 \mathrm{M} €$ & $438.16 \mathrm{M} €$ & $562.73 \mathrm{M} €$ & $870.65 \mathrm{M} €$ \\
$(-100 \%)$ & $(+9.97 \%)$ & $(+12.00 \%)$ & $(+9.91 \%)$ & $(+7.31 \%)$ \\
& {$[31.93 € / \mathrm{tCO} 2 \mathrm{e}]$} & {$[32.87 € / \mathrm{tCO} 2 \mathrm{e}]$} & {$[40.52 € / \mathrm{tCO} 2 \mathrm{e}]$} & {$[33.72 € / \mathrm{tCO} 2 \mathrm{e}]$} \\
\hline $54.625 \mathrm{M} €$ & $491.55 \mathrm{M} €$ & $424.94 \mathrm{M} €$ & $548.33 \mathrm{M} €$ & $853.96 \mathrm{M} €$ \\
$(-75 \%)$ & $(+7.16 \%)$ & $(+8.70 \%)$ & $(+7.10 \%)$ & $(+5.25 \%)$ \\
{$[34.69 € / \mathrm{tCO} 2 \mathrm{e}]$} & {$[35.73 € / \mathrm{tCO} 2 \mathrm{e}]$} & {$[44.04 € / \mathrm{tCO} 2 \mathrm{e}]$} & {$[36.68 € / \mathrm{tCO} 2 \mathrm{e}]$} \\
\hline $107.25 \mathrm{M} €$ & $479.74 \mathrm{M} €$ & $412.70 \mathrm{M} €$ & $534.93 \mathrm{M} €$ & $838.43 \mathrm{M} €$ \\
$(-50 \%)$ & $(+4.58 \%)$ & $(+5.50 \%)$ & $(+4.48 \%)$ & $(+3.34 \%)$ \\
& {$[37.46 € / \mathrm{tCO} 2 \mathrm{e}]$} & {$[38.60 € / \mathrm{tCO} 2 \mathrm{e}]$} & {$[47.56 € / \mathrm{tCO} 2 \mathrm{e}]$} & {$[39.63 € / \mathrm{tCO} 2 \mathrm{e}]$} \\
\hline $160.875 \mathrm{M} €$ & $468.76 \mathrm{M} €$ & $401.44 \mathrm{M} €$ & $523.01 \mathrm{M} €$ & $824.34 \mathrm{M} €$ \\
$(-25 \%)$ & $(+2.19 \%)$ & $(+2.60 \%)$ & $(+2.15 \%)$ & $(+1.60 \%)$ \\
& {$[40.23 € / \mathrm{tCO} 2 \mathrm{e}]$} & {$[41.47 € / \mathrm{tCO} 2 \mathrm{e}]$} & {$[51.08 € / \mathrm{tCO} 2 \mathrm{e}]$} & {$[42.57 € / \mathrm{tCO} 2 \mathrm{e}]$} \\
\hline $214.5 \mathrm{M} €$ & $458.72 \mathrm{M} €$ & $391.09 \mathrm{M} €$ & $512.00 \mathrm{M} €$ & $811.36 \mathrm{M} €$ \\
& & & & \\
& {$[42.99 € / \mathrm{tCO} 2 \mathrm{e}]$} & {$[44.34 € / \mathrm{tCO} 2 \mathrm{e}]$} & {$[54.61 € / \mathrm{tCO} 2 \mathrm{e}]$} & {$[45.52 € / \mathrm{tCO} 2 \mathrm{e}]$} \\
\hline
\end{tabular}

Table 9. Calculated Real Option Value and investment trigger price as a function of Initial Capital Expenditure. Percentage changes in ROV are shown in brackets, and investment trigger prices are shown in square brackets. 


\begin{tabular}{|c|c|c|c|c|}
\hline \multirow{2}{*}{$T \& S$ Cost } & \multicolumn{2}{|c|}{ Phase Two } & \multicolumn{2}{|c|}{ Phase Four } \\
\hline & GBM & STLT & GBM & STLT \\
\hline $\begin{array}{c}3.68 € / \mathrm{tCO}_{2} \mathrm{e} \\
(-50 \%)\end{array}$ & $\begin{array}{c}484.00 \mathrm{M} € \\
(+5.50 \%) \\
{\left[36.36 € / \mathrm{tCO}_{2} \mathrm{e}\right]}\end{array}$ & $\begin{array}{c}416.87 \mathrm{M} € \\
(+6.60 \%) \\
{\left[37.44 € / \mathrm{tCO}_{2} \mathrm{e}\right]}\end{array}$ & $\begin{array}{c}539.77 \mathrm{M} € \\
(+5.42 \%) \\
{\left[46.17 € / \mathrm{tCO}_{2} \mathrm{e}\right]}\end{array}$ & $\begin{array}{c}844.15 \mathrm{M} € \\
(+4.04 \%) \\
{\left[38.46 € / \mathrm{tCO}_{2} \mathrm{e}\right]}\end{array}$ \\
\hline 7.3 & $\begin{array}{c}458.72 \mathrm{M} € \\
{\left[42.99 € / \mathrm{tCO}_{2} \mathrm{e}\right]}\end{array}$ & $\begin{array}{c}391.09 \mathrm{M} € \\
{\left[44.34 € / \mathrm{tCO}_{2} \mathrm{e}\right]}\end{array}$ & $\begin{array}{c}512.00 \mathrm{M} € \\
{\left[54.61 € / \mathrm{tCO}_{2} \mathrm{e}\right]}\end{array}$ & $\begin{array}{c}811.36 \mathrm{M} € \\
{\left[45.52 € / \mathrm{tCO}_{2} \mathrm{e}\right]}\end{array}$ \\
\hline $\begin{array}{c}11.03 € / \mathrm{tCO}_{2} \mathrm{e} \\
(+50 \%)\end{array}$ & $\begin{array}{c}437.63 \mathrm{M} € \\
(-4.60 \%) \\
{\left[49.65 € / \mathrm{tCO}_{2} \mathrm{e}\right]}\end{array}$ & $\begin{array}{c}369.08 \mathrm{M} € \\
(-5.60 \%) \\
{\left[51.26 € / \mathrm{tCO}_{2} \mathrm{e}\right]}\end{array}$ & $\begin{array}{c}488.72 \mathrm{M} € \\
(-4.55 \%) \\
{\left[63.04 € / \mathrm{tCO}_{2} \mathrm{e}\right]}\end{array}$ & $\begin{array}{c}782.47 \mathrm{M} € \\
(-3.56 \%) \\
{\left[52.58 € / \mathrm{tCO}_{2} \mathrm{e}\right]}\end{array}$ \\
\hline
\end{tabular}

Table 10. Calculated Real Option Value and investment trigger price as a function of Transport and Storage Cost. Percentage changes in ROV are shown in brackets, and investment trigger prices are shown in square brackets. 


\begin{tabular}{|c|c|c|c|c|}
\hline \multirow{2}{*}{ Penalty (\%) } & \multicolumn{2}{|c|}{ Phase Two } & \multicolumn{2}{|c|}{ Phase Four } \\
\hline & GBM & STLT & GBM & STLT \\
\hline $\begin{array}{c}0 \% \\
(-15 \%)\end{array}$ & $\begin{array}{c}524.66 \mathrm{M} € \\
(+14.40 \%) \\
{\left[27.77 € / \mathrm{tCO}_{2} \mathrm{e}\right]}\end{array}$ & $\begin{array}{c}458.19 \mathrm{M} € \\
(+17.20 \%) \\
{\left[28.83 € / \mathrm{tCO}_{2} \mathrm{e}\right]}\end{array}$ & $\begin{array}{c}584.33 \mathrm{M} € \\
(+14.10 \%) \\
{\left[35.25 € / \mathrm{tCO}_{2} \mathrm{e}\right]}\end{array}$ & $\begin{array}{c}899.20 \mathrm{M} € \\
(+10.80 \%) \\
{\left[29.56 € / \mathrm{tCO}_{2} \mathrm{e}\right]}\end{array}$ \\
\hline $\begin{array}{c}5 \% \\
(-10 \%)\end{array}$ & $\begin{array}{c}498.74 \mathrm{M} € \\
(+8.70 \%) \\
{\left[32.84 € / \mathrm{tCO}_{2} \mathrm{e}\right]}\end{array}$ & $\begin{array}{c}432.11 \mathrm{M} € \\
(+10.50 \%) \\
{\left[34.00 € / \mathrm{tCO}_{2} \mathrm{e}\right]}\end{array}$ & $\begin{array}{c}557.24 \mathrm{M} € \\
(+8.80 \%) \\
{\left[41.68 € / \mathrm{tCO}_{2} \mathrm{e}\right]}\end{array}$ & $\begin{array}{c}865.57 \mathrm{M} € \\
(+6.70 \%) \\
{\left[34.88 € / \mathrm{tCO}_{2} \mathrm{e}\right]}\end{array}$ \\
\hline $15 \%$ & $\begin{array}{c}458.72 \mathrm{M} € \\
{\left[42.99 € / \mathrm{tCO}_{2} \mathrm{e}\right]}\end{array}$ & $\begin{array}{c}391.09 \mathrm{M} € \\
{\left[44.34 € / \mathrm{tCO}_{2} \mathrm{e}\right]}\end{array}$ & $\begin{array}{c}512.00 \mathrm{M} € \\
{\left[54.61 € / \mathrm{tCO}_{2} \mathrm{e}\right]}\end{array}$ & $\begin{array}{c}811.36 \mathrm{M} € \\
{\left[45.52 € / \mathrm{tCO}_{2} \mathrm{e}\right]}\end{array}$ \\
\hline $\begin{array}{c}20 \% \\
(+5 \%)\end{array}$ & $\begin{array}{c}442.50 \mathrm{M} € \\
(-3.50 \%) \\
{\left[48.08 € / \mathrm{tCO}_{2} \mathrm{e}\right]}\end{array}$ & $\begin{array}{c}374.15 \mathrm{M} € \\
(-4.30 \%) \\
{\left[49.53 € / \mathrm{tCO}_{2} \mathrm{e}\right]}\end{array}$ & $\begin{array}{c}494.09 \mathrm{M} € \\
(-3.50 \%) \\
{\left[61.06 € / \mathrm{tCO}_{2} \mathrm{e}\right]}\end{array}$ & $\begin{array}{c}788.00 \mathrm{M} € \\
(-2.90 \%) \\
{\left[50.85 € / \mathrm{tCO}_{2} \mathrm{e}\right]}\end{array}$ \\
\hline
\end{tabular}

Table 11. Calculated Real Option Value and investment trigger price as a function of CCS Energy Output Penalty. Percentage changes in ROV are shown in brackets, and investment trigger prices are shown in square brackets. 


\begin{tabular}{|c|c|c|c|c|}
\hline \multirow{2}{*}{$\begin{array}{c}\text { Construction } \\
\text { (Years) }\end{array}$} & \multicolumn{2}{|c|}{ Phase Two } & \multicolumn{2}{|c|}{ Phase Four } \\
\hline & GBM & STLT & GBM & STLT \\
\hline s. & $\begin{array}{c}461.26 \mathrm{M} € \\
(+0.55 \%) \\
{\left[40.88 € / \mathrm{tCO}_{2} \mathrm{e}\right]}\end{array}$ & $\begin{array}{c}393.67 \mathrm{M} € \\
(+0.66 \%) \\
(42.10 € / \mathrm{tCO} 2 \mathrm{e}]\end{array}$ & $\begin{array}{c}517.46 \mathrm{M} € \\
(+1.10 \%) \\
{[50.78 € / \mathrm{tCO} 2 \mathrm{e}]}\end{array}$ & $\begin{array}{c}817.84 \mathrm{M} € \\
(+0.80 \%) \\
{\left[43.11 € / \mathrm{tCO}_{2} \mathrm{e}\right]}\end{array}$ \\
\hline 1 & $\begin{array}{c}458.72 \mathrm{M} € \\
{\left[42.99 € / \mathrm{tCO}_{2} \mathrm{e}\right]}\end{array}$ & $\begin{array}{c}391.09 \mathrm{M} € \\
{\left[44.34 € / \mathrm{tCO}_{2} \mathrm{e}\right]}\end{array}$ & $\begin{array}{c}512.00 \mathrm{M} € \\
{[54.61 € / \mathrm{tCO} 2 \mathrm{e}]}\end{array}$ & $\begin{array}{c}811.36 \mathrm{M} € \\
{\left[45.52 € / \mathrm{tCO}_{2} \mathrm{e}\right]}\end{array}$ \\
\hline 2 & $\begin{array}{c}453.99 \mathrm{M} € \\
(-1.03 \%) \\
{\left[45.72 € / \mathrm{tCO}_{2} \mathrm{e}\right]}\end{array}$ & $\begin{array}{c}386.28 \mathrm{M} € \\
(-1.23 \%) \\
{\left[47.35 € / \mathrm{tCO}_{2} \mathrm{e}\right]}\end{array}$ & $\begin{array}{c}502.60 \mathrm{M} € \\
(-1.80 \%) \\
{[59.67 € / \mathrm{tCO} 2 \mathrm{e}]}\end{array}$ & $\begin{array}{c}800.66 \mathrm{M} € \\
(-1.32 \%) \\
{\left[48.62 € / \mathrm{tCO}_{2} \mathrm{e}\right]}\end{array}$ \\
\hline 3 & $\begin{array}{c}446.68 \mathrm{M} € \\
(-2.62 \%) \\
{\left[48.31 € / \mathrm{tCO}_{2} \mathrm{e}\right]}\end{array}$ & $\begin{array}{c}379.48 \mathrm{M} € \\
(-2.97 \%) \\
{\left[50.24 € / \mathrm{tCO}_{2} \mathrm{e}\right]}\end{array}$ & $\begin{array}{c}490.27 \mathrm{M} € \\
(-4.20 \%) \\
{[64.83 € / \mathrm{tCO} 2 \mathrm{e}]}\end{array}$ & $\begin{array}{c}786.58 \mathrm{M} € \\
(-3.05 \%) \\
{\left[51.43 € / \mathrm{tCO}_{2} \mathrm{e}\right]}\end{array}$ \\
\hline 4 & $\begin{array}{c}437.35 \mathrm{M} € \\
(-4.66 \%) \\
{\left[50.75 € / \mathrm{tCO}_{2} \mathrm{e}\right]}\end{array}$ & $\begin{array}{c}371.40 \mathrm{M} € \\
(-5.04 \%) \\
{\left[52.86 € / \mathrm{tCO}_{2} \mathrm{e}\right]}\end{array}$ & $\begin{array}{c}476.29 \mathrm{M} € \\
(-7.00 \%) \\
{[69.99 € / \mathrm{tCO} \mathrm{e}]}\end{array}$ & $\begin{array}{c}769.22 \mathrm{M} € \\
(-5.19 \%) \\
{\left[54.16 € / \mathrm{tCO}_{2} \mathrm{e}\right]}\end{array}$ \\
\hline 5 & $\begin{array}{c}426.28 \mathrm{M} € \\
(-7.07 \%) \\
{\left[53.09 € / \mathrm{tCO}_{2} \mathrm{e}\right]}\end{array}$ & $\begin{array}{c}361.84 \mathrm{M} € \\
(-7.48 \%) \\
{\left[55.43 € / \mathrm{tCO}_{2} \mathrm{e}\right]}\end{array}$ & $\begin{array}{c}460.41 \mathrm{M} € \\
(-10.10 \%) \\
{[74.78 € / \mathrm{tCO} 2 \mathrm{e}]}\end{array}$ & $\begin{array}{c}749.39 \mathrm{M} € \\
(-7.64 \%) \\
{\left[56.66 € / \mathrm{tCO}_{2} \mathrm{e}\right]}\end{array}$ \\
\hline
\end{tabular}

Table 12. Calculated Real Option Value and investment trigger price as a function of construction time. Percentage changes in ROV are shown in brackets, and investment trigger prices are shown in square brackets. 


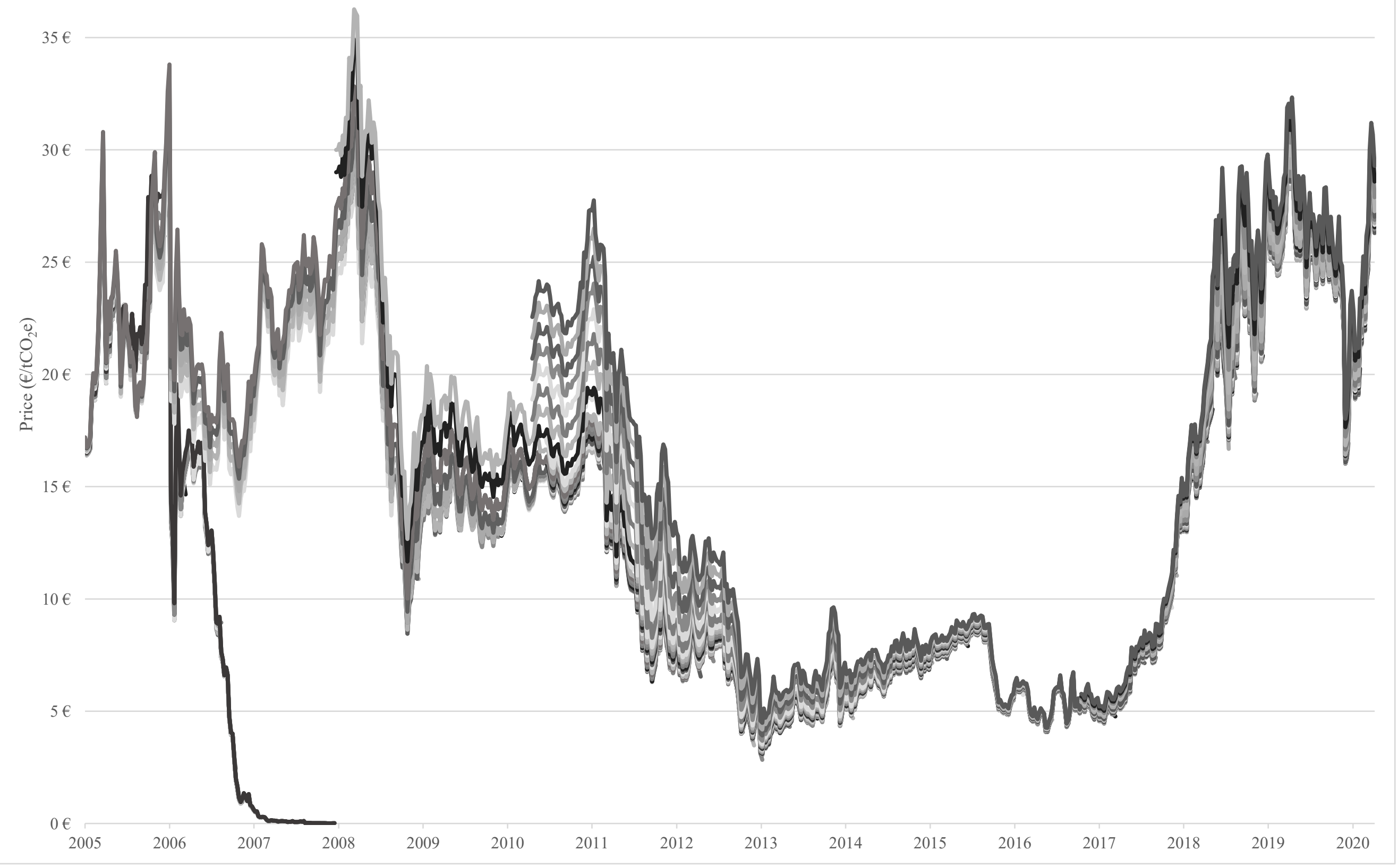




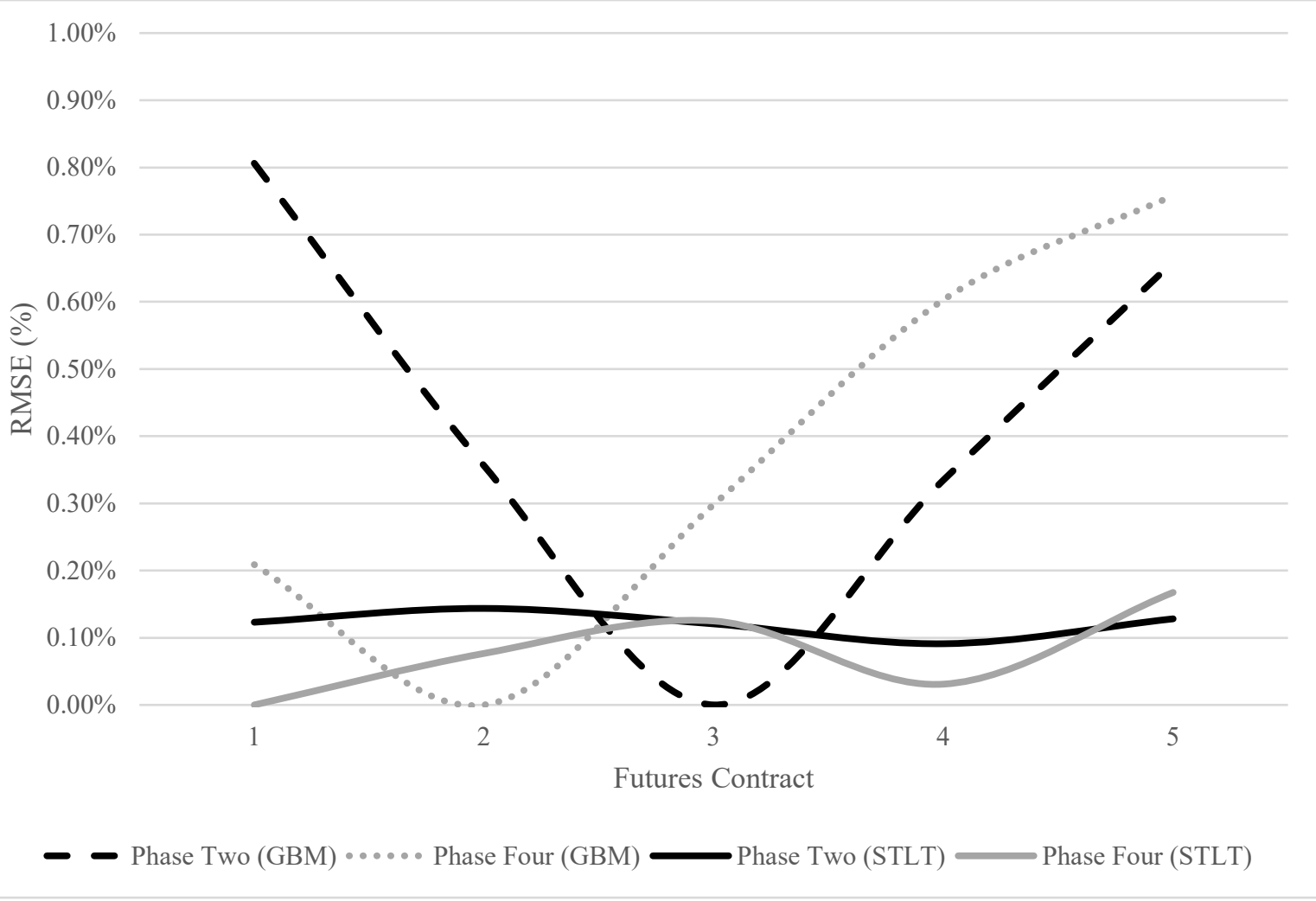

Figure 2. Errors in the Model Fit to the Logarithm of Futures Prices 


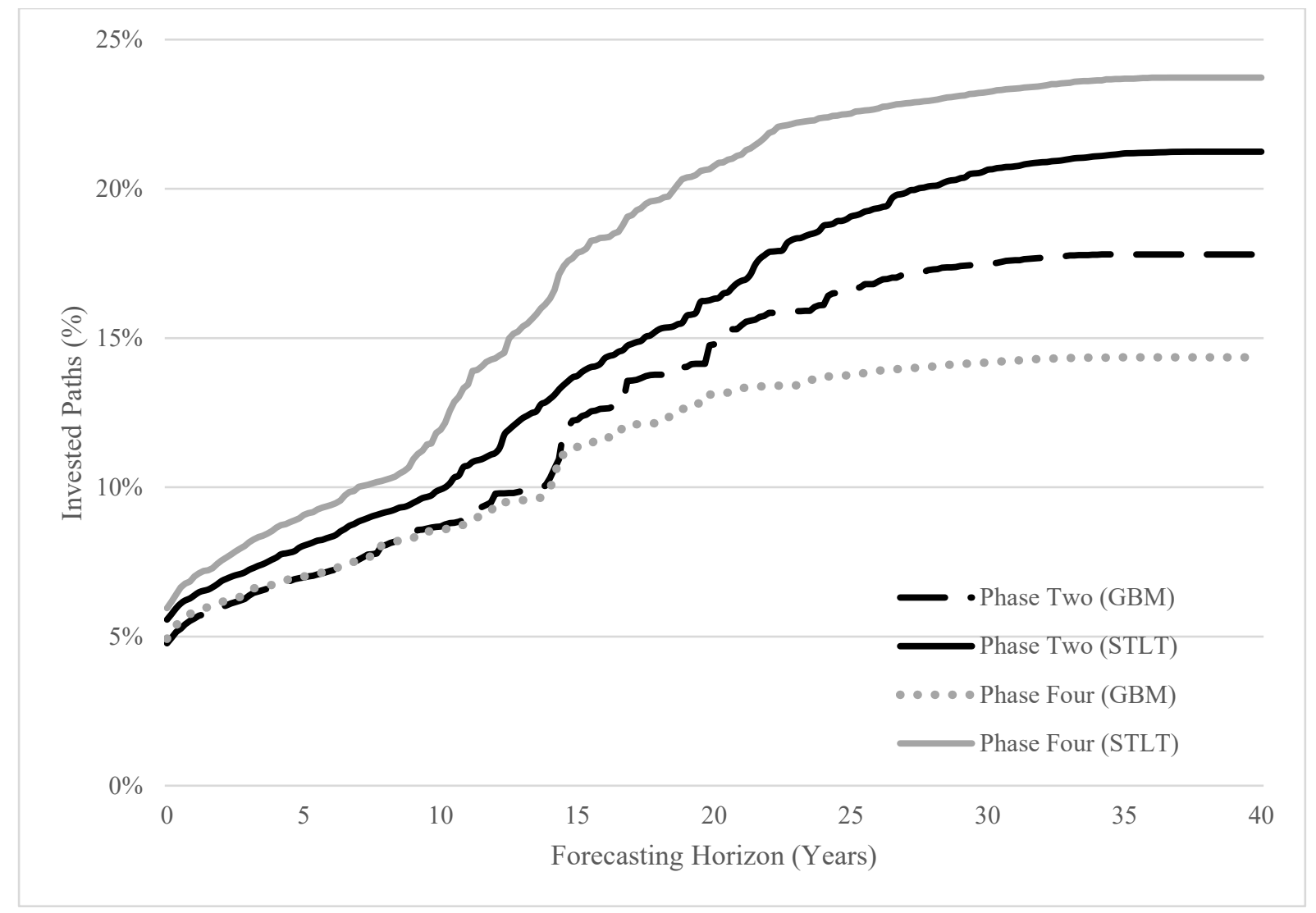

Figure 3. Proportion of invested paths over the forecasting horizon 


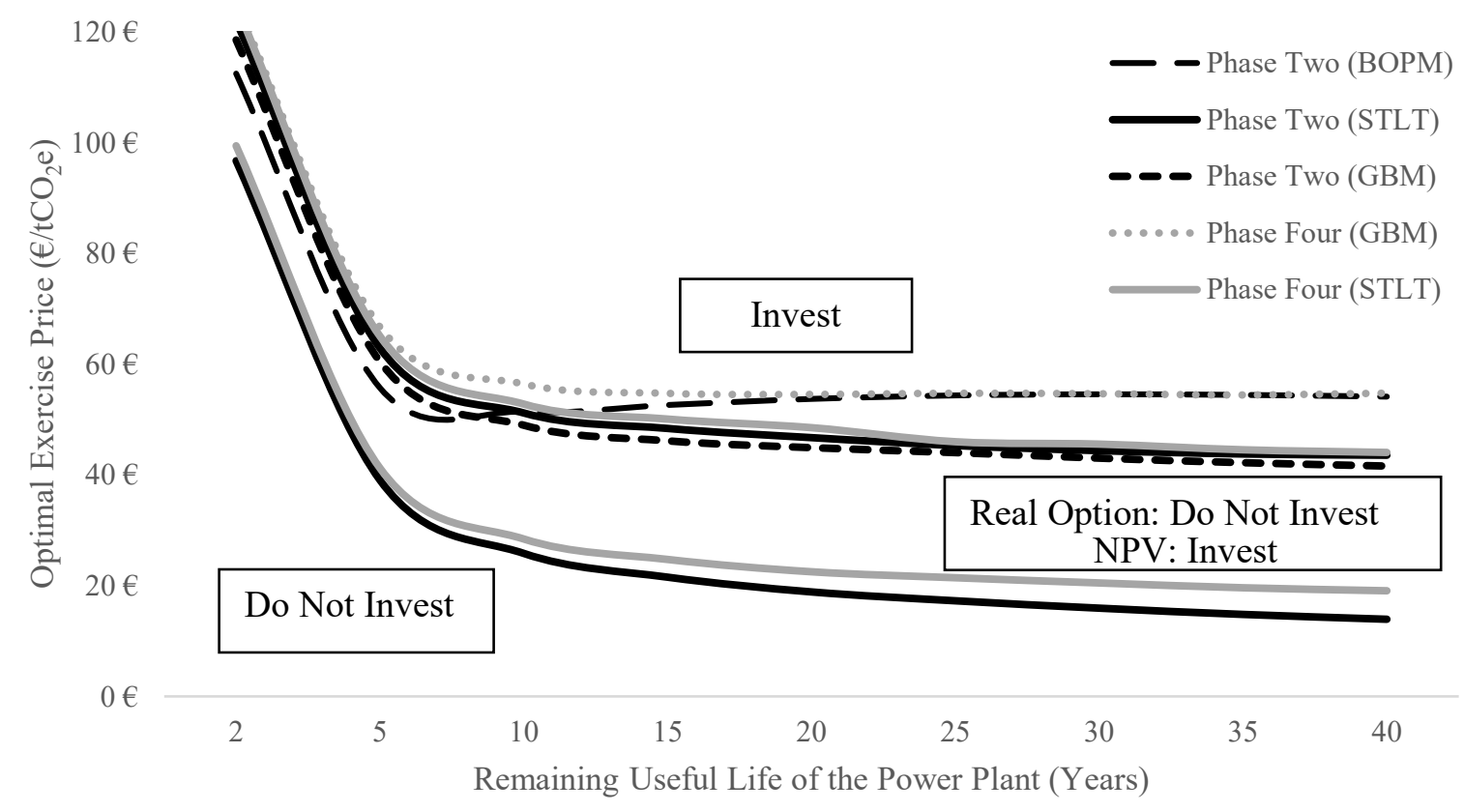

Figure 4. Investment and no-investment regions depending on useful life 